\title{
HUBUNGAN AKTIVITAS OLAHRAGA TERHADAP KEJADIAN SINDROM PRAMENSTRUASI MAHASISWI PROGRAM STUDIKEDOKTERAN DI UNIVERSITAS JAMBI TAHUN 2020
}

\author{
Karina Nabila Yasmin, Ahmad Syauqy, Rina Nofri Enis \\ Fakultas Kedokteran dan IImu Kesehatan Universitas Jambi \\ Corresponding author email: karinanabilayasmin09@gmail.com
}

\begin{abstract}
The menstrual cycle is one of the most important signs of a functioning productive system inwomen, menstruation that occurs sometimes experiences disorders such as cycle disorders, dysmenorrhea, and premenstrual syndrome (PMS). In this syndrome more than 150 signs have been identified, some of which are: abdominal cramps, boredom, flatulence, breast tenderness, acne, back aches and headaches, joint aches and pains, weight loss, lack of energy, changes in appetite, constipation, increased heart rate. Exercise increases the level of circulating endorphins (increases happiness), reduces adrenal cortisol for a short time and provides an analgesic effect. Aerobic exercise is recommended for women with PMS because it reduces premenstrual symptoms. This study was conducted to see whether sports activities can affect the incidence of premenstrual syndrome in students of medical study program at Jambi University in 2020. This research is an observational analytic research type to determine the relationship between two variables, this study uses a retrospective approach. Respondents were 75 students of the medical studyprogram at Jambi University in 2020 who were taken by proportional random sampling. Data was collectedby filling out a questionnaire using a premenstrual syndrome questionnaire using google form and for sports activities using the interview method through a zoom meeting. The premenstrual syndrome questionnaire using sPAF contains 10 questions and the sports activity interview contains 3 questions. Data analysis usedare fisher's exact test. There is no significant relationship between sports activities and the incidence of premenstrual syndrome. The results of the analysis test using fisher's exact test resulted in a p value of 0.867 ( $p>0.05)$. Sports activities don't affect the incidence of premenstrual syndrome
\end{abstract}

\section{Keywords : Premenstrual syndrome, Sports activities}

\section{ABSTRAK}

Siklus menstruasi adalah salah satu tanda paling penting sistem produktif berfungsi pada wanita, menstruasi yang terjadi terkadang diikuti dengan gangguan-gangguan seperti gangguan siklus, dysmenorrhea, dan sindrom premenstruasi (PMS). Pada sindrom ini lebih dari 150 tanda telah diidentifikasi, beberapa di antaranya adalah: kram perut, kebosanan, perut kembung, nyeri payudara, jerawat, punggungsakit dan sakit kepala, nyeri sendi dan nyeri otot, berat badan bertambah, kekurangan energi, Perubahan nafsu makan dan haus, sembelit, peningkatan denyut jantung. Olahraga meningkatkan tingkat endorfin yang bersirkulasi (meningkatkan kebahagiaan), mengurangi kortisol adrenal untuk waktu yang singkat dan memberikan efek analgesic. Olahraga aerobik dianjurkan untuk wanita dengan PMS karena itu mengurangi gejala pramenstruasi. Penelitian ini dilakukan untuk melihat apakah aktivitas olahraga dapat mempengaruhi kejadian sindrom pramenstruasi pada mahasiswi program studi kedokteran di Universitas Jambi pada tahun 
2020. Penelitian ini merupakan Jenis penelitian bersifat analitik observasional untuk mengetahui hubungan antara dua variabel, penelitian ini menggunakan pendekatan retrospektif. Responden berjumlah 75 mahasiswi program studi kedokteran di Universitas Jambi pada tahun 2020 yang diambil dengan Proporsional random sampling. Dilakukan pengumpulan data dengan pengisian kuisioner menggunakan kuesioner sindrom pramenstruasi dengan menggunakan google form dan untuk aktifitas olahraga akan menggunakan metode wawancara melalui zoom meeting. Kuesioner sindrom pramenstruasi yang menggunakan SPAF berisi 10 pertanyaan dan wawancara aktifitas olahraga berisi 3 pertanyaan. Analisis data menggunakan analisis fisher's exact test. Tidak terdapat hubungan signifikan antara aktivitas olahraga dengan kejadian sindrom pramenstruasi. Hasil uji analisis dengan menggunakan fisher's exact test menghasilkan nilai $p \quad 0,867$ ( $p>0,05)$. Aktivitas olahraga tidak berhubungan terhadap kejadian sindrom pramenstruasi.

Kata Kunci : Sindrom pramenstruasi, Aktivitas olahraga

\section{PENDAHULUAN}

Setiap bulan secara periodik, seorang wanita normal akan mengalami peristiwa reproduksi yang disebut menstruasi. Siklus menstruasi adalah salah satu tanda paling penting sistem produktif berfungsi pada wanita, menstruasi yang terjadi terkadang diikuti dengan gangguan- gangguan seperti gangguan siklus, dysmenorrhea, dan sindrom premenstruasi/Premenstrual Syndrome $\quad$ (PMS). ${ }^{1} \quad$ Sindrom premenstruasi mengacupada serangkaian gejala berulang itu dimulai pada akhir fase sekresi siklus menstruasi (5-7 hari sebelum menstruasi) dan berakhir pada fase folikuler (2-4 harisetelah menstruasi). Pada sindrom ini lebih dari 150 tanda telah diidentifikasi, beberapa di antaranya adalah: kram perut, kebosanan, perut kembung, nyeri dan nyeri payudara, jerawat, punggung sakit dan sakitkepala, nyeri sendi dan nyeri otot, berat badan bertambah, kekurangan energi, Perubahan nafsu makan dan haus, sembelit, peningkatan denyut jantung.
Karena tingginya prevalensi sindrom ini dan peran wanita dalam keluarga dan masyarakat, perawatan itu penting. Prevalensi gejala-gejala ini bervariasi sesuai dengan faktor-faktor seperti budaya, sikap, usia, olahraga, nutrisi, dan penyakit yangmendasari nya. ${ }^{2}$

Berdasarkan laporan World Health Organization (WHO). PMS memiliki prevalensi lebih tinggi di negara-negara Asiadibandingkan dengan negara-negara Barat. Hasil penelitian American College Obstetricians and Gynecologists (ACOG) di Sri Lanka tahun 2012, melaporkan bahwa gejala PMS dialami sekitar 65,7 remaja putri. Hasil studi Mahin Delara di Iran tahun 2012,ditemukan sekitar 98,2\% perempuan yang berumur 18-27 tahun mengalami paling sedikit 1 gejala PMS derajat ringan atau sedang. Prevalensi PMS di Brazil menunjukkan angka 39\%, dan di Amerika 34\% wanita mengalami PMS. Prevalensi PMS di Asia Pasifik, di ketahui bahwa di negara Jepang PMS dialami oleh $34 \%$ populasi perempuan dewasa, Hongkong PMS dialami oleh $17 \%$ 
populasi perempuan dewasa, Pakistan PMS dialami oleh $13 \%$ populasi perempuan dewasa dan Australia dialami oleh $44 \%$ perempuan dewasa. ${ }^{3}$

Sebagian besar wanita menganggap bahwa PMS bukan suatu kondisi yang serius, sehingga tidak melakukan upaya pencegahan ataupun pengobatan, padahal sindrom premenstruasi ini dapat juga berubah menjadi kondisi yang serius. Salah satu yang dapat dilakukan untuk mengurangi gejala PMS adalah dengan melakukan perubahan gaya hidup. Hal-hal seperti membatasi konsumsi kafein dan olahraga teratur dapat mengurangi PMS pada wanita. Olahraga yoga, aerobik, ataupun peregangan sederhana bisa mengurangi gangguan-gangguan PMS seperti kram, sakit punggung, nyeri dan ketegangan otot, dan stress. Manfaat dari olahraga yang bisa kita dapatkan, namun kebiasaan berolahraga sudah jarang sekali dimiliki olehmasyarakat terutama perempuan. ${ }^{1}$

Olahraga meningkatkan tingkat endorfin yang bersirkulasi (meningkatkan kebahagiaan), mengurangi kortisol adrenal untuk waktu yang singkat dan memberikan efek analgesic. Olahraga aerobik dianjurkan untuk wanita dengan PMS karena itu mengurangi gejala pramenstruasi. Dalam sebuah penelitian, tiga bulan olahraga aerobik dilaporkan mengurangi gejala pramenstruasi pada wanita yang tidak banyak bergerak. Olahraga seperti berjalan, bersepeda, berenang dan berlari dipandang sebagai cara yang baik untuk menekan stress dan menghilangkan sindrom pramenstruasi. ${ }^{4}$
Menurut penelitian Pratiwi1 menyebutkan bahwa ada hubungan antara aktivitas olahraga dengan sindrom premenstruasi dengan arah hubungan negatif yaitu semakin tinggi aktivitas olahraga maka semakin rendah tingkat sindrom premenstruasi. Sedangkan menurut penelitian Fatul menyatakan tidak adanya hubungan tingkat aktivitas fisik dengan kejadian pramenstrual syndrome. ${ }^{5}$

Berdasarkan hal hal yang diungkapkan diatas peneliti tertarik untuk melihat hubungan aktivitas olahraga dengan kejadian sindrom pramenstruasi mahasiswi program studi kedokteran di Universitas Jambi.

\section{METODE}

Penelitian ini merupakan Jenis penelitian bersifat analitik observasional untuk mengetahui hubungan antara dua variabel, penelitian ini menggunakan pendekatan retrospektif. Responden berjumlah 75 mahasiswi program studi kedokteran di Universitas Jambi pada tahun 2020 yang diambil dengan Proporsional random sampling. Dilakukan pengumpulan data dengan pengisian kuisioner menggunakan kuesioner sindrom pramenstruasi dengan menggunakan google form dan untuk aktifitas olahraga akan menggunakan metode wawancara melalui zoom meeting. Kuesioner sindrom pramenstruasi yang menggunakan SPAF berisi 10 pertanyaan terkait gejala sindrom pramenstruasi yang di derita responden. Setiap pertanyaan memiliki bobot nilai $1-6$ poin ( 1 = tidak mengalami, 2 = sangatringan, 3 = ringan, $4=$ sedang, 
5 = berat, $6=$ ekstrim). Hasil dari kuesioner dikategorikan menjadi dua, yaitu: i) Dismenorea jika skor total $\geq 11$, ii) Tidak dismenorea jika skor total $<11$. Untuk wawancara aktifitas olahraga berisi 3 pertanyaan berdasarkan frekuensi, dan durasi aktivitas olahraga aerobic yang baik. Hasil dari checklist dikategorikan menjadi dua, yaitu: i) Aktivitas olahraga baik jika responden memenuhi seluruh checklist wawancara, ii) Aktivitas olahraga kurang baik jika tidak memenuhi salah satu dari seluruh checklist. Analisis data menggunakan analisis fisher's exact test.

\section{HASIL DAN PEMBAHASAN}

Hasil dari penelitian ini disajikan dalam dua bentuk analisis data berupa analisis univariat dan bivariat. Analisis data univariat yaitu mengenai karakteristik respoden berdasarkan umur, usia pertama kali menstruasi, kebiasaan mengonsumsi obat anti nyeri saat dismenore, indeks massa tubuh, suku, riwayat keluarga inti mengalami PMS dan gambaran sindrom pramenstruasi mahasiswi program studi kedokteran di Universitas Jambi tahun 2020 serta gambaran aktivitas olahraga yang dilakukan mahasiswi program studi kedokteran di Universitas Jambi tahun 2020. Sedangkan analisis bivariat untuk mengetahui apakah terdapat hubungan antara aktivitas olahraga terhadap kejadian sindrom pramenstruasi mahasiswi program studi kedokteran di Universitas Jambi tahun2020.

\section{Responden berdasarkan usia}

Tabel 4.1 Responden Berdasarkan Usia

\begin{tabular}{ccc}
\hline Usia & Frekuensi & Persentase \\
\hline 18 tahun & 6 & 8,0 \\
19 tahun & 17 & 22.7 \\
20 tahun & 32 & 42.7 \\
21 tahun & 12 & 16.0 \\
22 tahun & 7 & 9,3 \\
23 tahun & 1 & 1,3 \\
Total & $\mathbf{7 5}$ & $\mathbf{1 0 0 . 0}$ \\
\hline
\end{tabular}

Tabel 4.1 menunjukkan frekuensi usia mahasiswi program studi kedokteran diUniversitas Jambi tahun 2020. Sebesar $8,0 \%$ berumur 18 tahun, $22,7 \%$ berumur 19 tahun, $42,7 \%$ berumur 20 tahun, $16,0 \%$ berumur 21 tahun, $9,3 \%$ berumur 22 tahun dan 1,3\% berumur 23 tahun.

\section{Responden Berdasarkan Usia Menarche}

Tabel 4.2 menunjukkan frekuensi usia menarche mahasiswi program studi kedokteran di Universitas Jambi tahun 2020. Sebesar 1,3\% menarche pada usia 10 tahun, 10,7\% pada usia 11 tahun, 32,0\% pada usia 12 tahun, $34,7 \%$ pada usia 13 tahun, $16,0 \%$ pada usia 14 tahun, 4,0\% pada usia 15 tahun, dan $1,3 \%$ pada usia 16 tahun. 
MEDIC, Volume 4, nomor 1, April 2021, Hal:218-226 Karina Nabila, dkk. Hubungan aktivitas...

Tabel 4.2 Berdasarkan Usia Menarche

\begin{tabular}{ccc}
\hline $\begin{array}{c}\text { Usia } \\
\text { Menarche }\end{array}$ & frekuensi & Persentase \\
\hline 10 tahun & 1 & 1.3 \\
11 tahun & 8 & 10.7 \\
12 tahun & 24 & 32.0 \\
13 tahun & 26 & 34,7 \\
14 tahun & 12 & 16.0 \\
15 tahun & 3 & 4.0 \\
16 tahun & 1 & 1.3 \\
total & $\mathbf{5}$ & $\mathbf{1 0 0 . 0}$
\end{tabular}

\section{Responden Berdasarkan Kebiasaan Meminum Obat Anti Nyeri Saat Dismenore}

Tabel 4.3 Kebiasaan Obat Anti Nyeri

\begin{tabular}{ccc}
\hline $\begin{array}{c}\text { Kebiasaan } \\
\text { Obat Anti } \\
\text { Nyeri }\end{array}$ & Frekuensi & Persentase \\
\hline Ya & 10 & 13.3 \\
Tidak & 65 & 86.7 \\
Total & 75 & $\mathbf{1 0 0 . 0}$ \\
\hline
\end{tabular}

Tabel 4.3 menunjukan frekuensi mahasiswi yang memiliki kebiasaan meminum obat anti nyeri saat dismenore. Sebesar 13,3\% memiliki kebiasaan meminum obat anti nyeri saat dismenore dan sebesar $86,7 \%$ tidak memiliki kebiasaanmeminum obat anti nyeri saat dismenore.

\section{Responden Berdasarkan Indeks Massa Tubuh}

Tabel 4.4 Berdasarkan IMT

\begin{tabular}{ccc}
\hline IMT & Frekuensi & Persentase \\
\hline Overweight & 12 & 16.0 \\
Normal & 48 & 64,0 \\
Underweight & 15 & 20.0 \\
Total & $\mathbf{7 5}$ & $\mathbf{1 0 0 . 0}$ \\
\hline
\end{tabular}

Tabel 4.4 menunjukkan frekuensi indeks massa tubuh (IMT) mahasiswi. Sebesar 16,0\% dikategorikan Overweight, sebesar $64,0 \%$ dikategorikan Normal, dan sebesar 20,0\% dikategorikan Underweight.

\section{Responden Berdasarkan Suku}

Tabel 4.5 Berdasarkan Suku

\begin{tabular}{ccc}
\hline Suku & Frekuensi & Persentase \\
\hline Melayu & 40 & 53.3 \\
Bugis & 2 & 2.7 \\
Minang & 13 & 17.3 \\
Jawa & 7 & 9.3 \\
Batak & 8 & 10.7 \\
Sunda & 2 & 2.7 \\
Bali & 1 & 1.3 \\
Nias & 1 & 1.3 \\
Tionghoa & 1 & 1.3 \\
Total & 75 & $\mathbf{1 0 0 . 0}$ \\
\hline
\end{tabular}

Tabel 4.5 menunjukkan frekuensi suku bangsa mahasiswi, sebesar 53,3\% bersuku Melayu, sebesar 2,7\% bersuku Bugis, 17,3\% bersuku Minang, 9,3\% bersuku Jawa, 10,7\% bersuku Batak, 2,7\% bersuku Sunda, 1,3\% bersuku Bali, 
1,3\% bersuku Nias, 1,3\% bersuku Tionghoa.

\section{Responden Berdasarkan Riwayat Keluarga Inti Mengalami PMS}

Tabel 4.6 Berdasarkan Riwayat Keluarga

\begin{tabular}{ccc}
\hline $\begin{array}{c}\text { Riwayat } \\
\text { Keluarga }\end{array}$ & $\begin{array}{c}\text { Frekuens } \\
\text { i }\end{array}$ & $\begin{array}{c}\text { Persenta } \\
\text { se }\end{array}$ \\
\hline Ada & 27 & 36.0 \\
Tidak ada & 48 & 64.0 \\
Total & $\mathbf{7 5}$ & $\mathbf{1 0 0 . 0}$ \\
\hline
\end{tabular}

Tabel 4.6 menunjukan mahasiswi yang memiliki riwayat keluarga inti mengalami PMS. Sebesar 36,0\% memiliki riwayat keluarga inti misalnya ibu kakak atau adik mengalami PMS, dan sebesar $64,0 \%$ tidak memiliki riwayat keluarga inti mengalami PMS.

\section{Gambaran Sindrom Pramenstruasi} Mahasiswi Program Studi Kedokteran di Universitas Jambi Tahun 2020

Tabel 4.7 Gambaran PMS mahasiswi

\begin{tabular}{ccc}
\hline $\begin{array}{c}\text { Sindrom } \\
\text { Pramenstruasi }\end{array}$ & $\begin{array}{c}\text { Frekuen } \\
\text { si }\end{array}$ & $\begin{array}{c}\text { Persenta } \\
\text { se }\end{array}$ \\
\hline Dismenore & 74 & 98,7 \\
Tidak Dismenore & 1 & 1,3 \\
Total & $\mathbf{7 5}$ & $\mathbf{1 0 0 , 0}$ \\
\hline
\end{tabular}

Tabel 4.7 menunjukkan sebesar $98,7 \%$ mahasiswi mengalami sindrom pramenstruasi sedangkan $1,7 \%$ tidak mengalami sindrom pramenstruasi.

Berdasarkan hasil penelitian ini didapatkan hasil menunjukkan sebesar 98,7\% mahasiswi mengalami sindrom pramenstruasi sedangkan $1,7 \%$ tidak mengalami sindrom pramenstruasi. Dari hasil yang didapatkan ternyata mahasiswi program studi kedokteran di Universitas Jambi mayoritas mengalami sindrom pramenstruasi. Hasil yang berbeda dari penelitian yang dilakukan sebelumnya oleh Fatul yang menunjukkan yaitu sebesar $(78,7 \%)$ mengalami gejala ringan dan $(17,2 \%)$ mengalami gejala yang berat, hal inibisa dikarenakan responden pada penelitianFatul adalah mahasiswi Fakultas IImu Sosialdan IImu politik yang waktu nya lebih fleksibel daripada responden penelitian ini yaitu mahasiswi fakultas kedokteran yang waktunya kurang fleksibel dan bisa saja tidak memiliki waktu untuk melakukan aktivitas olahraga. ${ }^{5}$

Hasil penelitian ini juga menunjukkan bahwa penurunan produktivitas seperti merasa tidak sanggup menghadapi masalah, merasa sedih dan juga mudah tersinggung lebih banyak dialami oleh penderita sindrom pramenstruasi dibandingkan dengan yang tidak mengalami sindrom pramenstruasi.

$$
\text { Gejala-gejala sindrom }
$$
pramenstruasi meliputi gejala fisik, emosi dan perilaku. Gejala fisik diantaranya; kelemahanumum (lekas letih, pegal, linu), acne (jerawat), nyeri pada kepala, punggung, perut bagian bawah, nyeri pada payudara, Gangguan saluran cerna (rasa penuh/kembung), konstipasi, diare, perubahan nafsu makan, sering merasa lapar (food cravings). Gejala emosi dan perilaku; mood menjadi labil (mood swings), iritabilitas (mudah tersinggung), depresi, kecemasan, gangguan konsentrasi, insomnia (sulit tidur). ${ }^{6,7}$ 


\section{Gambaran Aktivitas Olahraga Yang \\ Dilakukan Mahasiswi Program Studi Kedokteran di Universitas Jambi Tahun 2020}

Tabel 4.8 Gambaran Aktivitas Olahraga

\begin{tabular}{lcc}
\hline $\begin{array}{l}\text { Aktivitas } \\
\text { Olahraga }\end{array}$ & Frekuensi & Persentase \\
& & \\
\hline Baik & 10 & 13,3 \\
Kurang Baik & 65 & 86,7 \\
Total & $\mathbf{7 5}$ & $\mathbf{1 0 0 , 0}$ \\
\hline
\end{tabular}

Tabel 4.8 menunjukkan aktivitas olahraga mahasiswi, sebesar 13,3\% melakukan olahraga yang baik sedangkan $86,7 \%$ memiliki tingkat aktivitas olahraga yang kurang baik.

Hasil penelitian didapatkan menunjukkan sebesar 13,3\% mahasiswi melakukan olahraga yang baik sedangkan $86,7 \%$ memiliki tingkat aktivitas olahraga yang kurang baik. Dapat disimpulkan bahwamayoritas mahasiswi program studi kedokteran di Universitas Jambi tahun 2020 memiliki tingkat aktivitas olahraga yang kurang baik.

Olahraga memiliki manfaat yang banyak untuk kesehatan tubuh, misalnya meningkatkan fungsi jantung, pembuluh darah, sirkulasi darah, sistem pernafasan dan proses metabolisme, serta kemampuan tubuh untuk menangkal ber macam-macam penyakit, baik yang di sebabkan oleh infeksi maupun bukan karena infeksi (degeneratif). Olahraga juga dapat mengurangi gejala gangguan psikis, misalnya tekanan jiwa (stress) dan ketegangan jiwa (anxiety). ${ }^{8}$

\section{Hubungan Antara Aktivitas Olahraga}

Terhadap Kejadian Sindrom

Pramenstruasi Mahasiswi Program

Studi Kedokteran di Universitas Jambi

Tahun 2020

Dari hasil uji normalitas data mahasiswa didapatkan sebaran data normal menggunakan uji Kolmogorov-Smirnov, sehingga uji hipotesis yang digunakan adalah Uji Chi Square. Dibawah ini disajikan tabel 4.9 mengenai hubungan antaraaktivitas olahraga terhadap kejadian sindrom pramenstruasi program studi kedokteran di Universitas Jambi:

Tabel 4.9 Hubungan Olahraga dengan PMS

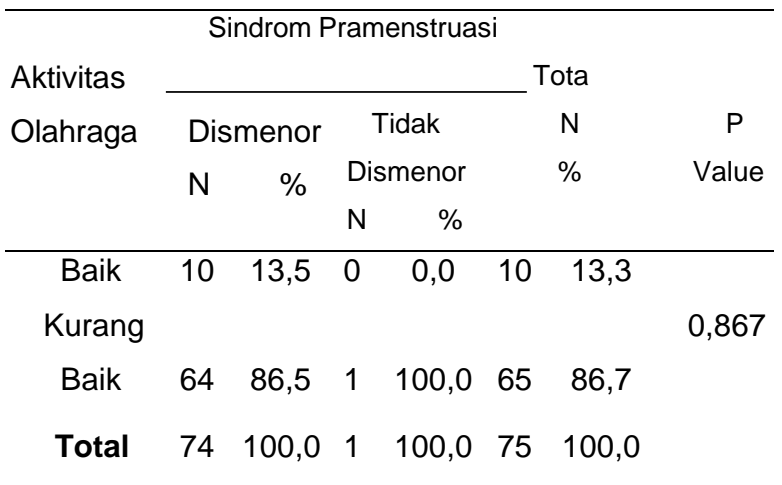

Tabel 4.9 menunjukan hasil analisis dengan menggunakan uji Chi Square tetapi dikarenakan ada 2 sel yang tidak normal sehingga menggunakan fisher's exact test. Hasil uji analisis ini menghasilkan nilai $p 0,867(p>0,05)$ yang berarti tidak ada hubungan aktivitas olahraga terhadap kejadian sindrom pramenstruasi.

Hasil analisa data menunjukkan hasil analisis dengan menggunakan uji Chi Square tetapi dikarenakan ada 2 sel 
yang tidak normal sehingga menggunakan fisher's exact test. Dimana pada tabel 4.9 diketahui bahwa tidak ada hubungan yang bermakna antara aktivitas olahraga dengan kejadian sindrom pramenstruasi (nilai p 0,867).

Hasil penelitian ini sejalan dengan hasil penelitian Fatul yaitu tidak ada hubungan antara aktivitas olahraga dengan kejadian sindrom pramenstruasi karena pada sebagian besar wanita yang melakukan olahraga yang baik dan teratur tetap terjadi sindrom pramenstruasi yang signifikan. Penelitian Fatul menghasilkan value $p=0,678$ dan nilai chi square 0,678 . Nilai signifikan yang diperoleh 0,678> $(0,05)$ maka hipotesis nol diterima atau Ho diterima, berarti menyatakan bahwa tidak ada hubungan antara premenstrual syndrome dengan tingkat aktivitas fisik. ${ }^{5}$

Hasil analisis 1 orang yang tidak mengalami dismenore pada penelitian ini tidak juga memiliki aktivitas olahraga yangbaik, hasil ini dapat juga mendukung teorl bahwa aktivitas olahraga tidak mempengaruhi sindrom premenstruasi. Diperkirakan bahwa latihan atau tingkat aktivitas olahraga memicu produksi endorfin, obat alami yang meningkatkan toleransi wanita terhadap perubahan premenstrual syndrome dalam kehidupannya. Beberapa mekanisme biologis dapat menjelaskan hubungan tingkat aktivitas olahraga dengan sindroma premenstruasi. Tingkat aktivitas olahraga dapat meningkatkan endorfin, menurunkan estrogen dan hormon steroid lainnya, meningkatkan transportasi oksigen dalam otot, mengurangi kadar kortisol dan meningkatkan keadaan psikologis. ${ }^{9}$

Terdapat perbedaan hasil dengan beberapa peneliti sebelumnya, bisa jadi disebabkan oleh beberapa faktor yaitu disebabkan oleh tingkat aktivitas olahraga yang berbeda, mayoritas pada responden penelitian ini tidak melakukan aktivitas olahraga yang baik dan juga banyak faktor lain yang mempengaruhi sindrom pramenstruasi yang tidak bisa dilihat melaluialat kuisioner, jika menggunakan SPAF responden melihat secara subyektif, karenasetiap gejala memiliki respon yang berbeda, penilaian yang subyektif dari gambaran gejala sindrom pramenstruasi yang membuat setiap responden memiliki penilaian yang berbeda-beda.

\section{KESIMPULAN}

Berdasarkan hasil penelitian dan pembahasan yang telah dijelaskan dan dijabarkan pada bab-bab sebelumnya, kesimpulan yang dapat ditarik dari penelitianini adalah sebagai berikut:

1. Hasil Penelitian didapatkan mayoritas mahasiswi program studi kedokteran di Universitas Jambi tahun 2020 mengalami dismenore

2. Hasil Penelitian didapatkan mayoritas mahasiswi program studi kedokteran di universitas jambi tahun 2020 memiliki tingkat aktivitas olahraga yang kurang baik

3. Hasil penelitian didapatkan tidak terdapat hubungan antara aktivitas olahraga dengan kejadian sindrom 
MEDIC, Volume 4, nomor 1, April 2021, Hal:218-226 Karina Nabila, dkk. Hubungan aktivitas...

pramenstruasi pada mahasiswi Universitas Jambi tahun 2020

program studi kedokteran di

\section{DAFTAR PUSTAKA}

1. Pratiwi AM. Aktivitas Olahraga dengan Kejadian Sindrom Premenstruasi pada Anggota Perempuan UKM INKAI UNS. J Ners dan Kebidanan Indones. 2016;2(2):76.

2. Mohebbi Dehnavi Z, Jafarnejad F, Sadeghi Goghary S. The effect of 8weeks aerobic exercise on severity of physical symptoms of premenstrual syndrome: A clinical trial study. BMC Womens Health. 2018;18(1):1-7.

3. Surmiasih S. Aktivitas Fisik dengan Sindrom Premenstruasi Pada Siswa SMP. J Aisyah J IImu Kesehat. 2016;1(2):71-8.

4. Yesildere Saglam $\mathrm{H}$, Orsal O. Effect of exercise on premenstrual symptoms: A systematic review. Complement Ther Med. 2020;48(August 2019).

5. Fatul S. Hubungan Premenstrual Syndrome dengan Tingkat Aktivitas Fisik Pada Mahasiswi Fakultas IImu Sosial dan IImu Politik Universitas Airlangga. 2017;VI(2):234.

6. Gnanasambanthan S, Datta S. Premenstrual syndrome. Obstet Gynaecol Reprod Med [Internet]. 2019;29(10):281-5. Available from: https://doi.org/10.1016/j.ogrm.2019.06.003

7. Link M. Premenstrual syndrome (PMS). Encycl Endocr Dis. 2018;7(1):432-5.

8. Sugiarti RK\& ST. Hubungan Antara Kebiasaan Olahraga Dengan Kejadian Nyeri Haid Primer Pada Remaja. J Publ Kebidanan. 2018;9(1):114-23.

9. Sherwood L. Fisiologl Manusia (Human Physiology: From Cells fo Systems) Edisi 6. Dep Physiol Pharmacol Sch Med West Virginia Univ. 2012;Edisi 6:999 